\title{
Whatever you think is best, doctor
}

\author{
Stephen Hancocks OBE \\ Editor-in-Chief
}

As practical people, terms such as 'the democratisation of medical knowledge' tend to find us smiling wanly and putting our heads back into someone's mouth. We deal in materials and tissues rather than concepts and philosophies, understand mechanics and enjoy problem solving. Yet such matters necessarily have a place in our world and the research papers in this issue provide yet another example of how dentistry is a strange conundrum of complex simplicity. ${ }^{1,2}$

The starting point was the National Institute for Health and Clinical Excellence (NICE) recommendations in 2008 on antibiotic prophylaxis in relation to infective endocarditis (IE). These were, effectively, a reversal or contradiction of the previous guidelines by changing from prescribing antibiotics prior to dental treatment, to regarding it as not necessary. Essentially, in comparing the risks of anaphylactic shock and allergic reactions to antibiotics against those of suffering as a result of developing IE, the former were the greater. However, such an apparently abrupt change had immediate implications for our relationships with patients affected by the ghoul of IE.

The difficulty, of course, was 'convincing' patients that all that they had been told previously had turned out not to be true; the discomfort, disadvantage and inconvenience had been for nothing and the effect of the paraphernalia had been about zero.

\section{MULTI-FACTORED CONSEQUENCES}

In talking to both clinicians and patients to gauge their reactions in the aftermath of the NICE recommendations, the researchers discovered several interesting factors at play. Certainly patients were confused and doubtful about the quality and robustness of the evidence that supported such an about turn in 'their' treatment. While understanding that on a population level the risks of the antibiotics outweighed those of sparking IE, since they had been receiving antibiotics for years and not been affected, where could be the harm to them personally? Further, if it did even theoretically mean that the risk to them was reduced, then they would prefer to continue having such prophylaxis, please. It is a difficult logic to attempt to counter or to undermine and is then compounded by the argument that, similar to so many other health issues, what is to say that by this time next week the opinion will be different again and will have turned full circle, placing them in potential harm in the meanwhile.

For patients it ultimately came down to a matter of trust in their practitioner, although also with some reassurance from a higher authority or independent power. But whereas in previous times patients were much more inclined to accept that which 'the doctor' said as being the beginning and end of the matter, the access to information (which is what 'the democratisation of medical knowledge' really means in everyday parlance) has meant a far greater questioning of what is correct and where 'the truth' can be found.

For practitioners, the angst did not stop there. Some were concerned that the imposition of the recommendations was an encroachment on their clinical freedom and decision making which rode roughshod over their cherished domain of knowing what was best for their patients. In fairness, the recommendations do provide leeway by stating that unquestionably the patient's welfare is the responsibility of the practitioner but the fact remains that in the face of an adverse event and subsequent legal scrutiny it would be an uphill struggle to explain deviations taken from the consensual norm.

Apart from highlighting particular issues in what is after all a very small, if important, area of our practising lives, the work does underline once again the importance of trust which is at the very heart of the relationship that a clinician maintains with their patient. It is special and it is an inherent quality of being a professional, a quality which no amount of regulation, building in of political safeguards or stumbling bureaucracy can or should replace. It is interesting that in the eventuality, most patients were persuaded by dint of their trust that the newly recommended path be taken, so the 'doctor knows best' attitude actually remains largely intact. What takes place in the interim however is rather different in that debate, discussion, education and consultation has to play a part and this takes both time and skill to initiate, facilitate and moderate. Far from being able to keep our heads down and hope that such awkward niceties might pass us by, our role as modern professionals dictates that we have to engage and allow for participation, however uncomfortable we find it personally. The crumb of comfort that I believe we can savour is that despite being assailed currently on what seems like every side we can, and still do, elicit the respect and trust of those we serve and treat. For practical people that is a significant satisfaction.

1. Soheilipour S, Scambler S, Dickinson C, Dunne S M, Burke M, Newton J T. Antibiotic prophylaxis in dentistry: part I. A qualitative study of professionals' views on the NICE guideline. Br Dent J 2011; 211: E1

2. Soheilipour S, Scambler S, Dickinson C, Dunne S M, Burke M, Newton J T. Antibiotic prophylaxis in dentistry: part II. A qualitative study of patient perspectives and understanding of the NICE guideline. Br Dent J 2011; 211: E2. 